\title{
Early Ontogeny of the Secondary Proliferative Population of the Embryonic Murine Cerebral Wall
}

\author{
T. Takahashi, ${ }^{1,2}$ R. S. Nowakowski, ${ }^{3}$ and V. S. Caviness, Jr. ${ }^{1}$ \\ 'Department of Neurology, Massachusetts General Hospital, Harvard Medical School, Boston, Massachusetts \\ 02114, ${ }^{2}$ Department of Pediatrics, Keio University School of Medicine, Tokyo 160, Japan, and ${ }^{3}$ Department of \\ Neuroscience and Cell Biology, UMDNJ-Robert Wood Johnson Medical School, Piscataway, New Jersey 08854
}

The present report is an analysis of the proliferative behavior of the secondary proliferative population (SPP) of the dorsomedial region of the embryonic mouse cerebral wall. It is based upon experiments undertaken on embryonic days 14-16 (E14-E16) and exploits methods in which proliferative cells are labeled in $S$ phase with either or both bromodeoxyuridine and tritiated thymidine. The SPP, which arises from the PVE by E13, is principally the progenitor population to the neuroglial population of the mature neocortex and subjacent cerebral wall. By the end of E14 the SPP comes to be distributed diffusely from the outer margin of the ventricular zone throughout subventricular zone and intermediate zone. The length of the cell cycle of the SPP is constant at approximately $15 \mathrm{hr}$ throughout this interval; thus, this population undergoes 1.6 cell cycles/24 $\mathrm{hr}$ or 3.2 cycles in the course of the $48 \mathrm{hr}$ period, E14-E16. Over this $48 \mathrm{hr}$ period, the SPP increases from $11 \%$ to $35 \%$ of the total proliferative population of the dorsomedial cerebral wall. The absolute size of the SPP increases nearly sixfold. With these values taken together it may be estimated that approximately $87 \%$ of postmitotic cells of the SPP reenter S phase after each cell division in this interval which means that only approximately $13 \%$ of the proliferative population exits the cycle. These findings illustrate the massive expansion of the SPP antecedent to the explosive diffusion of glial cells through the neocortex and subjacent cerebral wall as neuronal migration comes to completion and neocortical growth and differentiation accelerate.

[Key words: cerebral histogenesis, mouse, cell cycle, proliferation, gliogenesis, subventricular zone, ventricular zone]

The neurons and glial cells that form the neocortex and underlying cerebral wall arise from two distinct proliferative populations which lie deep within the cerehral hemisphere of the developing brain (Schaper, 1897; His, 1889, 1904; Boulder Committee, 1970; Schmechel and Rakic, 1979a; Sidman and Rakic,

Received Feb. 23, 1995; revised Apr. 26, 1995; accepted Apr. 27, 1995

This work was supported by NIH Grants NS 12005 and NS28061, NSF Grant BNS8921020, and a grant from NASA. T.T. was supported by a fellowship of The Medical Foundation, Inc., Charles A. King Trust, Boston, MA. We gratefully acknowledge valuable suggestions and other assistance of Pradeep Bhide, Sahoko Miyama, and Nancy Hayes.

Correspondence should be addressed to T. Takahashi, Department of Neurology, Massachusetts General Hospital, 25 Fruit Street, Boston, MA 02114.

Copyright 1995 Society for Neuroscience 0270-6474/95/156058-11\$05.00/0
1982; Levinson and Goldman, 1993; Takahashi et al., 1993, 1994). These two populations differ in their distributions within the cerebral wall, in the range of cell classes which they produce, and in their proliferative behavior. We have referred to these populations as the pseudostratified ventricular epithelium (PVE) and the secondary proliferative population (SPP), designations which have their origins in terminology originally employed by Sauer and the Boulder committee (Sauer, 1936, 1937; Boulder Committee, 1970; Takahashi et al., 1993).

The PVE lies immediately adjacent to the ventricle and is present from the outset of evagination of the cerebral hemi spheres. Its distribution corresponds closely to a compact architectonic stratum which has been designated the ventricular zone (VZ, Boulder Committee, 1970). It gives rise to the majority of neurons of the neocortex, but it is also a proliferative zone for the radial glial cells of the astroglial class (Levitt et al., 1981; Misson et al., 1988). In the course of the cell cycle this population undergoes "interkinetic nuclear migration" (Sauer, 1936, 1937; Sidman et al., 1959; Fujita, 1963). The cardinal feature of this interkinetic nuclear migration is the cyclical movement of the nuclei of the PVE cells beginning at the end of the M phase at the ventricular surface and rising through the PVE during G1. This cyclic movement is dependent upon the common attachment of all PVE cells to each other at the margin of the ventricle (Sauer, 1935, 1936; Fujita, 1960; Stensaas and Stensaas, 1968; Hinds and Ruffett, 1971; Levitt et al., 1981). Upon entry into S phase, the nuclei reverse direction and begin to move back toward the ventricular surface (Takahashi et al., 1992). The proliferative kinetics (Fujita, 1963; Shimada and Langman, 1970; Waechter and Jaensch, 1972; Hoshino et al., 1973; Schultz et al., 1974; Takahashi et al., 1993, 1994) and patterns of cell production (Angevine and Sidman, 1961; Berry and Rogers, 1965; Shimada and Langman, 1970; Sidman and Rakic, 1973; Fernandez and Bravo, 1974; Rakic, 1974; Caviness, 1982; Jackson and Hickey, 1985; Luskin and Shatz, 1985; McConnell, 1988; Bayer and Altman, 1991) have been characterized experimentally in diverse mammalian species.

The SPP arises from the primordial PVE (Smart, 1972; $\Lambda \mathrm{lt}$ man and Bayer, 1990a; Halliday and Cepko, 1992; Takahashi et al., 1993) but comes to have a more diffuse and widespread distribution, extending from the interface of $\mathrm{VZ}$ and subventricular zone (SVZ), where proliferative cells of the SPP and PVE actually intermingle, outward across the full width of the intermediate zone (IZ) to the base of the developing cortical strata (Takahashi et al., 1993). The distribution of SPP to the architectonically defined SVZ, in the depths of the IZ abutting the VZ, 


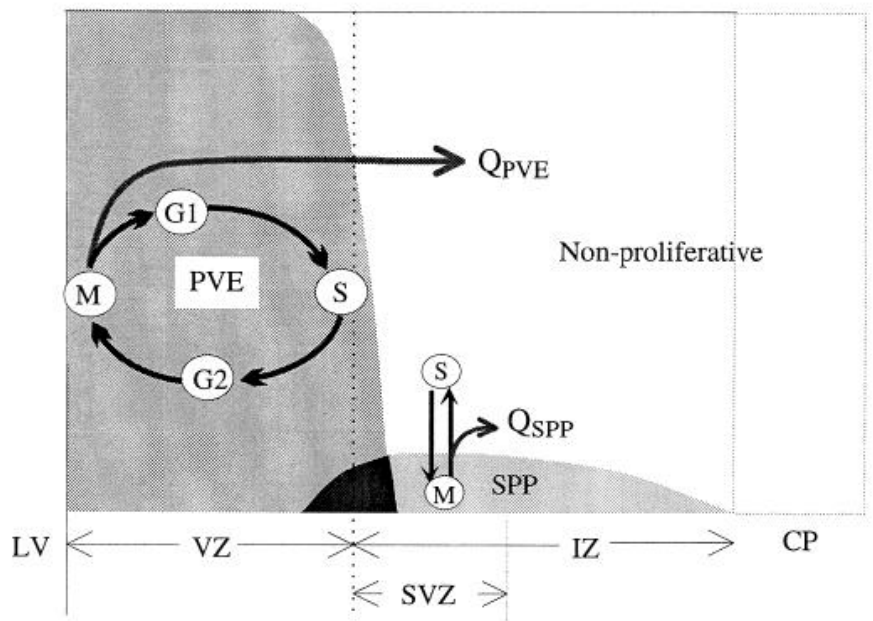

Figure 1. Relative magnitudes of proliferative populations ( $P V E$ and $S P P$ ) in relation to strata of the embryonic cerebral wall. The relative extent and sizes of the PVE and SPP are represented schematically with respect to the architectonically defined ventricular $(V Z)$, subventricular (SVZ), and intermediate (IZ) zones. The values for the PVE are assigned $100 \%$ on the ordinate, which indicates that the PVE has a GF of 1.0 and which ignores the small number of cells of the $Q$ fraction arising from the PVE $\left(Q_{P V E}\right)$ that may be migrating through the VZ. The assigned values on the ordinate for the SVZ and IZ are lower so as to indicate that many cells in these zones are "non-proliferative," either migrating neurons or glial cells in G0 and not part of the SPP. Cells of the PVE, but not those of the SPP, undergo interkinetic nuclear migration in the course of the cell cycle; the nuclei of those of the PVE, but not those of the SPP, shift inward toward the ventricular surface as they progress from $\mathrm{S}$ to $\mathrm{M}$ phase. $Q_{S P p}, Q$ fraction cells of the SPP; $L V$, lateral ventricle; $C P$, cortical plate.

was originally emphasized by the Boulder Committee. The SPP is a principal spawning ground for neuroglial cells (Smart, 1961; Smart and Leblond, 1961; Patterson et al., 1973; Privat, 1975; Mares and Bruckner, 1978; Todd and Smart, 1982; LeVine and Goldman, 1988a,b; Levinson and Goldman, 1993). Neurons of the olfactory bulb (Hinds, 1968; Luskin et al., 1992; Luskin, 1993; Lois and Alvarez-Buylla, 1994) and, possibly, also a small number of neurons destined for the neocortex (Reynolds and Weiss, 1992; Levinson and Goldman, 1993) may also undergo their terminal divisions in this proliferative population. Perhaps reflecting the fact that cells of the SPP, in contrast to those of the PVE, are not attached to each other as a pseudostratified epithelium, this population does not undergo interkinetic nuclear migration in the course of the cell cycle (Boulder Committee, 1970; Smart, 1972; Altman and Bayer, 1990a).

The shared histogenetic roles of the SPP and PVE have been emphasized in modern studies of cerebral development (Boulder Committee, 1970; Schmechel and Rakic, 1979b; Levinson and Goldman, 1993), but relatively little is known about the proliferative behavior and patterns of cell output of the SPP (Morshead and van der Kooy, 1992). In particular, the fundamental characteristics of the early proliferative behavior of the SPP have not been investigated experimentally. The relatively slow advance of analyses of the proliferative behavior of the SPP may be attributed at least in part to difficulties in distinguishing the SPP from other populations of cells, both proliferative and nonproliferative, with which the SPP is intermixed in the cerebral wall (Fig. 1). The critical fact that proliferative cells of the SPP and PVE actually intermingle at the interface of VZ and SVZ was emphasized in the prior paragraph. The fact that cells of the SPP are also distributed throughout the full width of the IZ means that these proliferating cells also are intermingled with the nonproliferative postmitotic neurons which arise from the PVE and migrate across the cerebral wall to reach the cortex. The proliferative cells of the SPP are also intermixed within the IZ with the somata of nonproliferating radial glial cells and probably other cells of glial lineage which have left the cell cycle during the epoch of neuronal migration but which may reenter the cycle in the course of subsequent development of the cerebral wall (Schmechel and Rakic, 1979a,b).

The present report is an analysis of the proliferative behavior of the SPP in the dorsomedial region of the embryonic mouse cerebral wall. It is based upon experiments undertaken on embryonic days 14-16 (E14-E16). Central to the analysis are experiments which distinguish the SPP from the other proliferative cells (i.e., the PVE) and from the nonproliferative cells with which the SPP is intermixed. The analysis provides estimates of both the proliferative kinetics of the SPP and of the fraction of cells that leaves this proliferative population during this interval. It also provides estimates of the fractional contribution of the SPP to the total cell population [i.e., the growth fraction (GF) in the zone of the SPP] as the cerebral wall changes drastically in width and composition during this dynamic period of early cerebral development. The embryonic dates surveyed here represent a critical histogenetic period which begins at the origin of the SPP from the PVE and continues to the final hours of neuronogenesis in the PVE. It ends before the massive ascent of glial cells into the neocortical zone, a phenomenon which occurs, for the most part, after the end of the period of neuronogenesis (LeVine and Goldman, 1988b; Altman and Bayer, 1990b; Bayer and Altman, 1991; Misson et al., 1991; Takahashi et al., 1991; Levinson and Goldman, 1993). Thus, these experiments are concerned with the earliest, formative phase of the progenitor population of the glial populations of the cerebral wall.

\section{Materials and Methods}

Animals. CD1 mice, used for these studies, were maintained on a $12 \mathrm{hr}$ (7:00 A.M. to 7:00 P.M.) light/dark schedule. Conception was ascertained by the presence of a vaginal plug with the day of conception considered to be E0. Plug-checks were conducted at 9:00 A.M.

$S$-Phase labeling. There were two labeling paradigms (see Results): (1) $1 \mathrm{hr}$ cohorts of cells labeled only with tritiated thymidine $\left({ }^{3} \mathrm{H}-\mathrm{TdR}\right.$, $5 \mu \mathrm{Ci} / \mathrm{kg}$ body weight) were established by an initial intraperitoneal injection of ${ }^{3} \mathrm{H}-\mathrm{TdR}$ at 9:00 A.M. followed at 10:00 A.M. by injection of bromodeoxyuridine (BUdR, $50 \mathrm{mg} / \mathrm{kg}$ body weight). Embryos were harvested $30 \mathrm{~min}$ later at 10:30 A.M. (2) For the percent labeled mitosis method, a single intraperitoneal injection of BUdR $(50 \mathrm{mg} / \mathrm{kg}$ body weight) was made at 9:00 A.M. with embryos harvested at increasing intervals throughout the total elapsed time longer than the length of the cell cycle $\left(T_{c}\right)$. The number of animals used was 4 animals from each of 2 litters (total of 8 animals) for the $1 \mathrm{hr}$ cohort labeling and 6 animals from each of 2 litters (total of 12) for each of the time points for the percent labeled mitosis method.

Histology. Embryos were removed by hysterotomy from dams deeply anesthetized by an intraperitoneal injection of a mixture of ketamine (50 mg/kg body weight) and xylazine (10 mg/kg body weight). The E14 embryos were decapitated, and the whole heads were fixed in $70 \%$ ethanol. E15 and E16 embryos were perfused via the left ventricle with $70 \%$ ethanol. The brains (the whole head from E14 embryos or brains dissected from the skull of E15 and E16 embryos) were postfixed overnight by immersion in $70 \%$ ethanol, dehydrated in graded ethanol solutions, embedded in paraffin, and sectioned at $4 \mu \mathrm{m}$ in the coronal plane. The sections were stained immunohistochemically for BUdR and counterstained with basic fuchsin as previously described (Takahashi et al., 1992, 1993). Procedures for the autoradiography following BUdR immunohistochemistry have been previously described (Takahashi et al., 1994). 


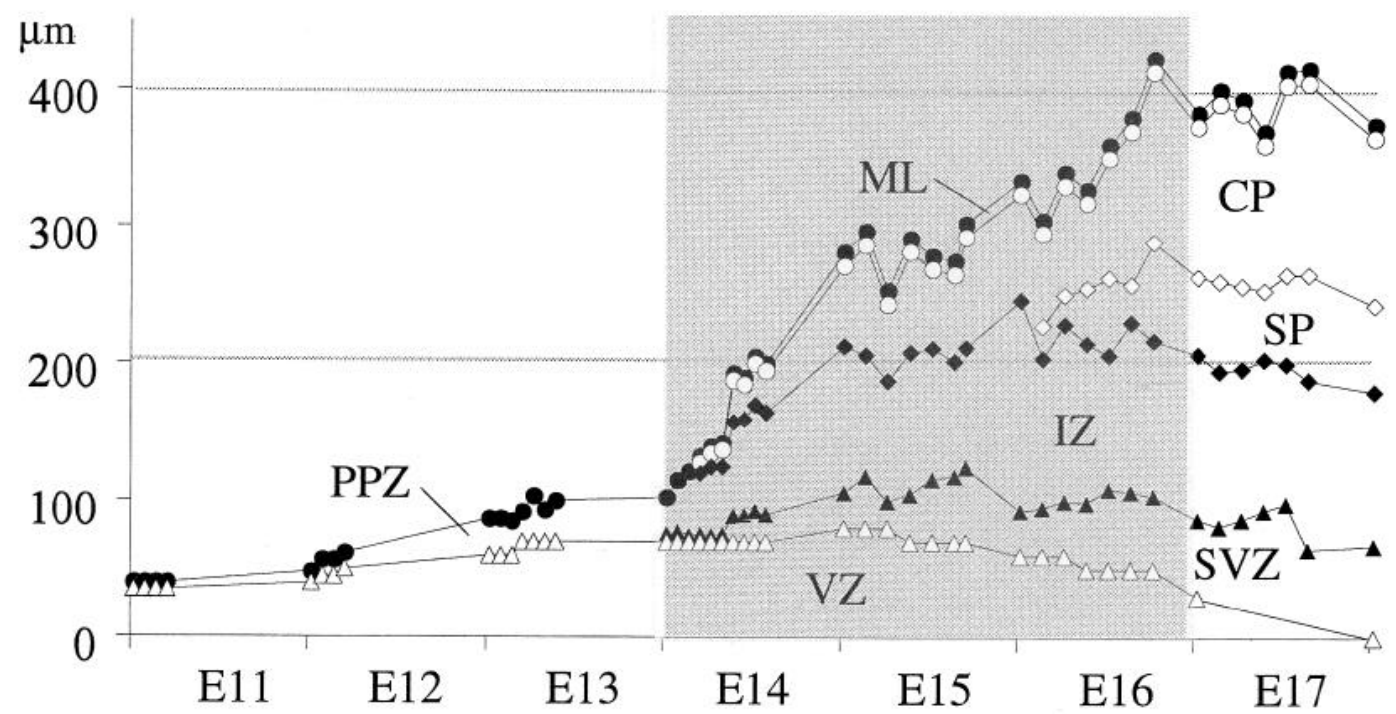

Figure 2. The changing pattern of cerebral stratification for the interval E11-E18 (modified from Takahashi et al., 1995). Only the 3 d interval beginning at 9:00 A.M. on E14 and continuing through E16 (shaded) is included in the present analysis of proliferative behavior of the SPP. Early on E14 the cerebral wall has only two strata, the primitive plexiform zone $(P P Z)$ and the ventricular zone (VZ). The width of the VZ approaches its maximum by E15 and then declines approximately $50 \%$ by the end of E16. The cortical strata $(M L$, molecular layer; $C P$, cortical plate; $S P$, subplate) and the intermediate zone (IZ), including the subventricular zone (SVZ), by contrast progressively increase in width.

Analysis. Analysis of the development of the hemispheric wall, in general, and of the SPP, in particular, is undertaken in a standard coronal sector of the dorsomedial cerebral wall (Takahashi et al., 1992, 1993, 1994). The sector is $100 \mu \mathrm{m}$ in its medial-to-lateral dimension and 4 $\mu \mathrm{m}$ (corresponding to section thickness) in its rostral-caudal dimension. The sector is divided in its radial dimension into bins $10 \mu \mathrm{m}$ in height and numbered 1,2,3, and so on from the ventricular margin for purposes of mapping the location of cell nuclei. The number of labeled and unlabeled cells were counted in each bin as previously described (Takahashi et al., 1992). A labeling index (LI) was calculated as the ratio of labeled to total cells.

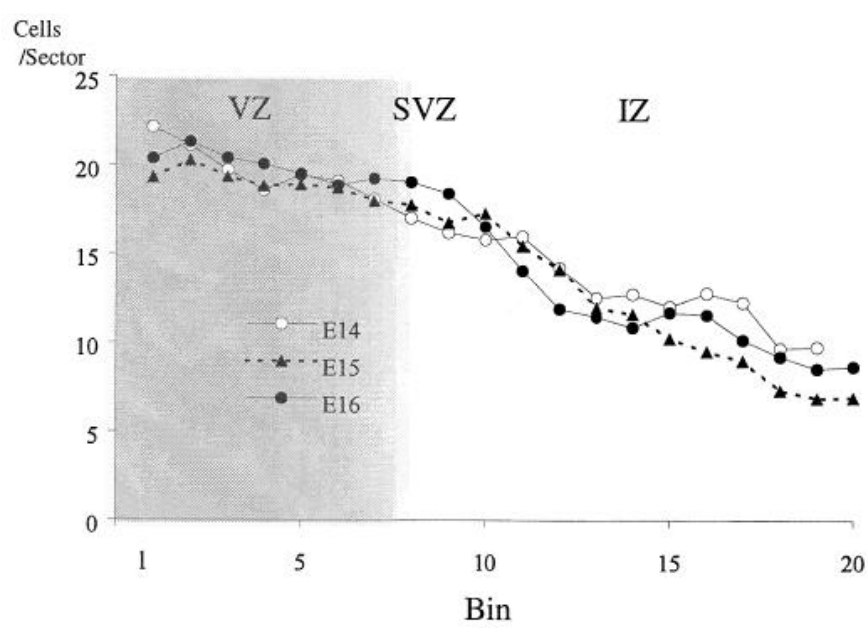

Figure 3. The density of cell nuclei in the successive bins of the cerebral wall for the interval E14-E16. The densities for corresponding depths in the cerebral wall are invariant at the three ages. The densities are maximum in the ventricular zone $(V Z)$ where they decline by approximately $20 \%$ from the ventricular margin to the interface with the subventricular zone $(S V Z)$. With progression across the intermediate zone $(I Z)$ the density drops progressively to values at the outer IZ which are less than $50 \%$ those at the SVZ-VZ margin. The SEM is less than $10 \%$ of the mean value at E14 $(n=12)$ and less than $5 \%$ at E15 and E16 $(n=20$ for each age $)$.

\section{Results}

\section{Cerebral stratification}

The proliferative population of the E14-E16 dorsomedial cerebral wall is constituted of cells of the SPP and PVE, exclusive of a few readily recognizable endothelial cells (Fig. 1, Takahashi et al., 1992). Mitotic figures of cells of the PVE are limited to the ventricular surface. Abventricular mitoses (cell divisions occurring at a distance from the ventricular surface), signaling the emergence of the SPP, are initially recognized on E13 at the outer margin of the $\mathrm{VZ}$ of the dorsomedial cerebral wall.

On E13 and continuing through 9:00 A.M. on E14, when this series of experiments is initiated, the cerebral wall is bilaminate with the $\mathrm{VZ}$ and overlying primitive plexiform zone comprising approximately $70 \%$ and $30 \%$, respectively, of the total width of the cerebral wall on early E14 (Fig. 2, Takahashi et al., 1992, 1993). Within the next $24 \mathrm{hr}$ the full stratification of the embryonic cerebral wall emerges. The VZ approaches its maximum width by $\mathrm{E} 15$ and then declines approximately $50 \%$ by the end of E16. The cortical strata (molecular layer, cortical plate and subplate) and the IZ including the SVZ, by contrast, progressively increase in width through E16. Concomitant with this change in the stratification of the cerebral wall, mitotic figures become dispersed through a wide field continuing from the outer VZ across the SVZ to the upper IZ. The cell packing density through the VZ and SVZ is approximately 20/bin in E14-16 (Fig. 3). The density through the IZ is substantially less, declining from approximately 15 cells/bin in the lower IZ to approximately 10 at the level of the external sagittal stratum.

\section{Distribution of cells in $S$ phase in the cerebral wall}

The distribution of cells in S phase of the collective SPP and PVE is estimated by immunohistological staining for BUdR, 0.5 hr following exposure to the tracer (Fig. 4). The distribution of BUdR labeled cells is expressed as an LI (LI profile), that is, labeled cells as a fraction of total cells in each radial $10 \mu \mathrm{m}$ bin. Thus, the analysis also provides the distribution of nuclei which 


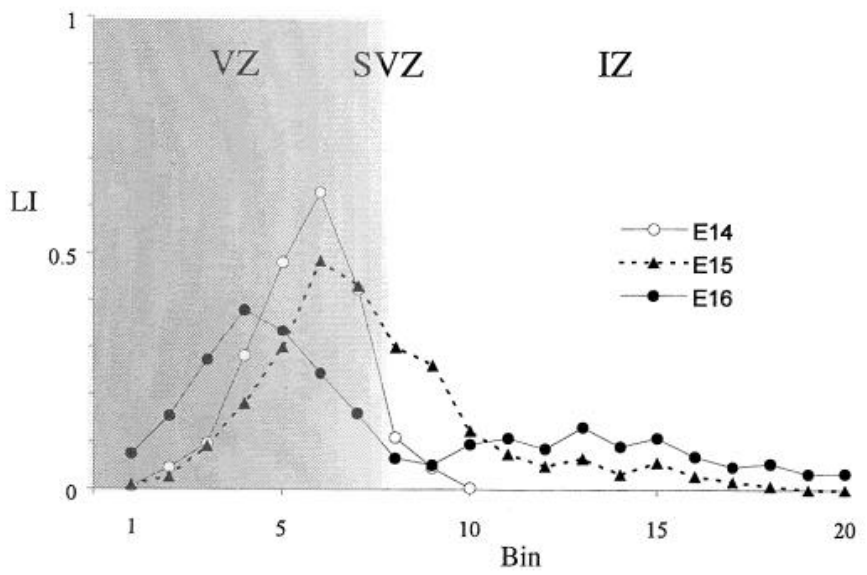

Figure 4. Labeling indices $(L I)$ with respect to depth in the cerebral wall $0.5 \mathrm{hr}$ following a single injection of BUdR. The LI in each bin corresponds to the number of cell nuclei in $\mathrm{S}$ phase as a fraction of the total number of cell nuclei in that bin. Large LI peaks are observed within the ventricular zone ( $V Z, S$-phase zone). In the subventricular $(S V Z)$ and intermediate (IZ) zones, by contrast, the concentration of labeled cells is relatively flat reflecting the fact that cells of the SPP do not undergo interkinetic nuclear migration. The LIs in the IZ are much lower than those of the VZ, because the SPP is intermixed with nonproliferative cells, that is, migrating neurons and glial cells in G0 phase. The SEM is less than $10 \%$ of the mean LI $(n=6)$ where the LI is greater than 0.1 . For bins with LI of less than 0.1 the SEM is less than 0.01 .

do not incorporate BUdR. Some of the unlabeled nuclei represent cycling cells not in $\mathrm{S}$ phase at the time of exposure to BUdR while the others are nuclei of nonproliferative cells of the cerebral wall.

The LI profile has a distinct peak in the outer half of the VZ (S-phase zone of the VZ, Takahashi et al., 1992) because PVE cells undergo interkinetic nuclear migration and $S$ phase of PVE cells occurs in the outer half of the VZ (Takahashi et al., 1992, 1993, 1995). In the IZ, by contrast, the concentration of labeled cells is relatively flat, and no peak in the distribution of labeled cells is evident (Fig. 4). This is consistent with the generally held belief that the nuclei of the SPP cells do not undergo systematic interkinetic movement, and furthermore, it indicates that their distribution is relatively uniform throughout the subcortical cerebral wall. The average LI in the IZ is approximately 0.05 at E15 and 0.1 at E16 (Fig. 4). Because the SPP, a small proliferative populationn relative to the PVE, is intermingled with the PVE at the interface of SVZ and VZ, the LI attributable to the SPP in the SVZ cannot be estimated by a simple S-phase labeling experiments.

For the reasons stated above, the distribution of cells in $\mathrm{S}$ phase within the VZ and the SVZ-IZ (Fig. 4) defines only approximately the differential distribution and relative sizes of the PVE and SPP populations in the cerebral wall. A small fraction of S-phase cells in the outer fringe of the VZ, and most but not all of the cells in the SVZ and all in the IZ will belong to the SPP whereas most in the VZ will belong to the PVE. Due to the overlap between the PVE and SPP at the interface of the VZ and SVZ (Fig. 1), a precise partition of the SPP and PVE populations requires a different strategy which is described in the following section.

\section{SPP-PVE partition}

The proliferative population at the interface of the VZ and SVZ includes cells of both SPP and PVE (Fig. 1). The nuclei of those of the PVE, but not those of the SPP, shift inward toward the ventricular surface as they progress from $\mathrm{S}$ to $\mathrm{M}$ phase. This difference in proliferative behavior provides a means of distinguishing the distributions of the two populations. This is done as follows.

Cells in S phase, belonging to both the SPP and PVE, were initially labeled by a single injection of ${ }^{3} \mathrm{H}-\mathrm{TdR}$, given at 9:00 A.M. on each of E14-E16. The ${ }^{3} \mathrm{H}-\mathrm{TdR}$ was followed in $1 \mathrm{hr}$ by a single injection of BUdR. As a result of exposure to the 2 tracers in succession, a cohort of SPP and PVE cells which leaves $\mathrm{S}$ phase to enter $\mathrm{G} 2$ phase in synchrony (a synchronous $1 \mathrm{hr}$ cohort) is labeled only with ${ }^{3} \mathrm{H}-\mathrm{TdR}$ (Takahashi et al., 1994). After an additional $0.5 \mathrm{hr}$, that is, $1.5 \mathrm{hr}$ after exposure to ${ }^{3} \mathrm{H}$-TdR (to assure that the entire population of cells in $\mathrm{S}$ phase is labeled with BUdR), the embryos were sacrificed. The $1.5 \mathrm{hr}$ survival time is shorter than the combined length of G2 and M phases and, thus, at the time of sacrifice all cells of the cohort, whether belonging to the PVE or SPP, would be in either G2 phase or prophase. The ${ }^{3} \mathrm{H}$-TdR-only labeled cells are readily distinguished from cells labeled with both ${ }^{3} \mathrm{H}-\mathrm{TdR}$ and BUdR or with BUdR alone (Fig. 5, Takahashi et al., 1994).

The G2-prophase distributions of the nuclei of cells of the synchronous $1 \mathrm{hr}$ cohort, in relation to depth in the cerebral wall are illustrated in Figure 6. Due to the movement of the nuclei of the PVE cells, as expected, the total cohort of labeled nuclei has become sorted into two subpopulations during the $1.5 \mathrm{hr}$ elapsed after exposure to ${ }^{3} \mathrm{H}-\mathrm{TdR}$. The more compact of the two subpopulations, corresponding to G2-prophase nuclei of cells of the PVE, is concentrated in the bins adjacent to the ventricle. The second subset, corresponding to G2-prophase nuclei of cells of the SPP lie further out in the cerebral wall with a wide distribution spanning the outer VZ and the overlying SVZ and IZ of the cerebral wall.

Because nuclei of cells of the SPP execute the complete cell cycle without moving, the spatial distribution of the SPP $1 \mathrm{hr}$ cohort illustrated in Figure 6 may be taken to represent the distribution of the entire SPP in the cerebral wall. The numbers of cells of the $1 \mathrm{hr}$ cohorts belonging to the PVE and the SPP and their totals are entered in Table 1, column 2.

\section{Cell cycle length of SPP $\left(\mathrm{T}_{\mathrm{C}(S P P)}\right)$ and PVE $\left(\mathrm{T}_{\mathrm{C}(P V E)}\right)$}

$T_{C(\mathrm{PVE})}$ was estimated elsewhere by the method of cumulative labeling with BUdR (Takahashi et al., 1993, 1995). For three reasons, this method of estimating $T_{C}$ is inapplicable to the SPP: (1) a large and unknown proportion of labeled cells within the SVZ-IZ will be migrating neurons arising from the PVE; (2) an unknown proportion of unlabeled nuclei in the SVZ-IZ will belong to radial glia which are "out of cycle," that is, in G0 phase; and (3) cells of the SPP which have left the cell division cycle do not leave the zone where the SPP is distributed. Thus, it is not possible to determine the true LI of the SPP in a cumulative S-phase labeling sequence.

The "percent labeled mitosis" method of determining the rate of change in the LI among mitotic figures following exposure to an S-phase marker (Sidman, 1970) is, however, suitable for an estimate of $T_{C(\mathrm{SPP})}$. (Note that this method estimates the $T_{C}$ for the most rapidly cycling cells and is insensitive to the range of $T_{C}$ among the total population of proliferative cells. That is, the presence of subpopulations which differ in terms of $T_{C}$ would not be recognized by this method. This approach is, in part, justified by the finding that the range of $T_{C}$ for cells of the PVE is small; Cai et al., 1993). Cells of the SPP, like those of the 


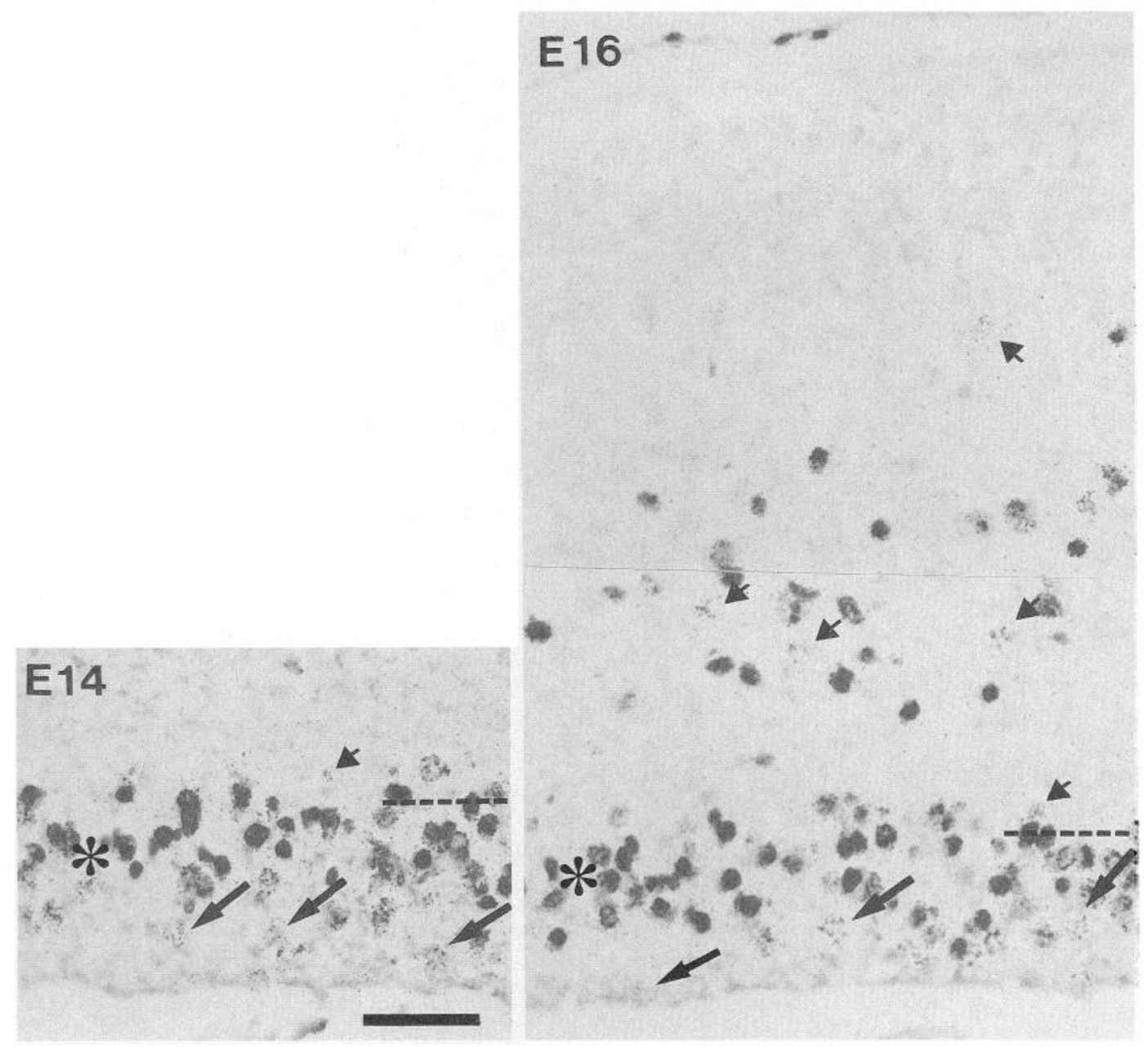

Figure 5. The dorsomedial region of the murine cerebral wall double labeled with BUdR and ${ }^{3} \mathrm{H}-\mathrm{TdR} .{ }^{3} \mathrm{H}-\mathrm{TdR}$, given by intraperitoneal injection at 9:00 A.M. on E14 (left) and E16 (right) was followed by an injection of BUdR at 10:00 A.M. and animal sacrifice at 10:30 A.M. Coronal 4 $\mu \mathrm{m}$ sections were stained immunohistochemically for BUdR then developed as autoradiograms for detection of ${ }^{3} \mathrm{H}-\mathrm{TdR}$. In the PVE, a cohort of cells labeled only with ${ }^{3} \mathrm{H}$-TdR (arrows) has separated from the S-phase zone $\left({ }^{*}\right)$ as interkinetic migration displaces their nuclei toward the ventricular margin. The cohort of SPP cells identified in this way (arrowheads), by contrast, do not undergo interkinetic nuclear migration. Scale bar: $40 \mu \mathrm{m}$ for both E14 and E16. Broken lines indicate VZ-SVZ border.

PVE, are assumed to proliferate asynchronously. Pregnant animals were injected with BUdR at 9:00 A.M. on each of the days E14-E16 and sacrificed after $0.5 \mathrm{hr} 1.0,1.5,2.0,12.5$ (E14), 13.0 (E15, E16), 15.5, $17.0 \mathrm{hr}$. The abventricular mitotic figures (therefore, belonging to the SPP) are readily visible within the sector across the subcortical strata of the cerebral wall (Takahashi et al., 1992). Each abventricular mitotic figure is scored as BUdR positive or BUdR negative. Then the proportion of abventricular mitotic figures labeled with BUdR (percent labeled mitosis of the SPP) was determined at each time point in the $100 \mu \mathrm{m}$ wide dorsomedial cerebral sector. $T_{\text {C(SPP) }}$ estimated in this way is found to remain unchanged at around $15 \mathrm{hr}$ over the E14-E16 interval (Fig. 7, Table 1, column 3). $T_{\text {CPVE), }}$ unlike $T_{\text {C(SPP) }}$, rather than remaining constant increases to $18.4 \mathrm{hr}$ by E16 (Table 1, column 3, Takahashi et al., 1995). The combined length of G2 and M phases of the SPP, corresponding to the interval between injection and $100 \%$ labeling of abventricular mitotic figures in the first cycle after the injections is invariant at $2 \mathrm{hr}$ for E14-E16 (Fig. 7).

If the BUdR injection were strictly a "pulse" exposure, providing S-phase labeling for only a matter of minutes following injection, the percent labeled mitosis method would also allow an estimate of the length of $\mathrm{S}$ phase $\left(T_{S}\right)$, corresponding to the interval between the $50 \%$ labeling levels on the upward and downward mitotic labeling slope for the initial cycle (Sidman, 1970). Because the BUdR injected intraperitoneally has a prolonged effective labeling time of at least $2 \mathrm{hr}$ (Takahashi et al., 1992), this method is inapplicable here for the direct estimation of $T_{S(\mathrm{SPP})}$ (and, therefore, the direct estimation of the length of G1 phase of the SPP).

\section{The sizes of the SPP $\left(\mathrm{N}_{S P P}\right)$ and PVE $\left(\mathrm{N}_{P V E}\right)$}

For any asynchronously proliferating population, the proportion of its cells that would be labeled in an $\times \mathrm{hr}$ cohort is equal to $x / T_{C}$; the magnitude of the population $(N)$ may be estimated as

$$
N x=N x * T_{C} / x,
$$

where $N x$ is the number of cells in a given cohort defined in any interval of $x$ hr. Thus, the magnitudes of the SPP and PVE populations can be derived from the size of their respective 1 hr cohorts, but only if the $T_{C}$ of each population is known. $N_{\mathrm{SPP}}$ and $N_{\text {PVE }}$ will be estimated from the numbers of each population 


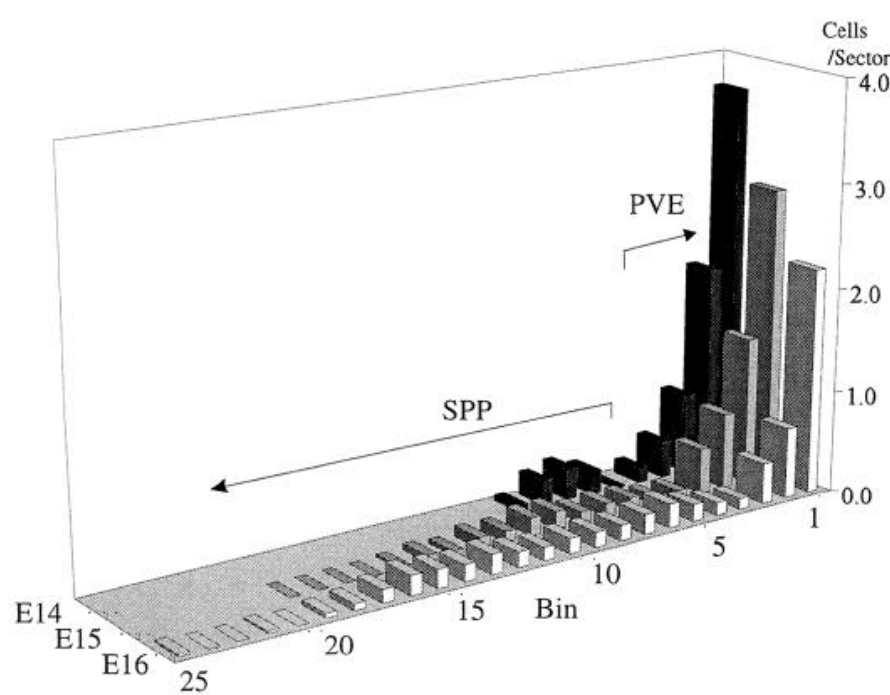

Figure 6. The number of cells of the $1 \mathrm{hr}$ cohort as a function of depth in the cerebral wall (bin). G2-prophase nuclei of cells belonging to the PVE, because of interkinetic nuclear migration form a substantial peak, inclined away from the S-phase zone of the PVE toward the ventricular margin. Those belonging to the SPP form the second peak further out in the cerebral wall with a wide distribution. The SEM is less than $10 \%$ of the mean value $(n=8)$ where the mean value is greater than 1.0. For bins with the mean value of less than 1.0 the SEM is less than 0.1 .

in the $1 \mathrm{hr}$ cohort $\left(N_{1 \mathrm{hr}}\right)$ and $T_{C}$ for the respective populations. That is, where $x=1 \mathrm{hr}$, Equation 1 becomes

$$
N=N_{\mathrm{lhr}} * T_{\mathrm{C}} / 1 \text {. }
$$

$N_{1 \text { hr }}$ and $T_{C}$ for each of the two populations have already been estimated by the $1 \mathrm{hr}$ cohort method using double S-phase makers (see "SPP-PVE partition," Table 1, column 2) and percent labeled mitosis method (see "Cell cycle length of SPP ( $\left.T_{C(\text { SPP) }}\right)$ and PVE $\left(T_{C(\mathrm{PVE})}\right)$, , Table 1 , column 3$)$, respectively.

Under suitable circumstances both BUdR and ${ }^{3} \mathrm{H}-\mathrm{TdR}$ may provide up to $100 \%$ sensitivity for detecting S-phase cells (Waechter and Jaensch, 1972; Takahashi et al., 1993). However, under the specific experimental conditions used here to estimate $N_{1 \mathrm{hr}}$, that is, an autoradiographic determination following only a rel-

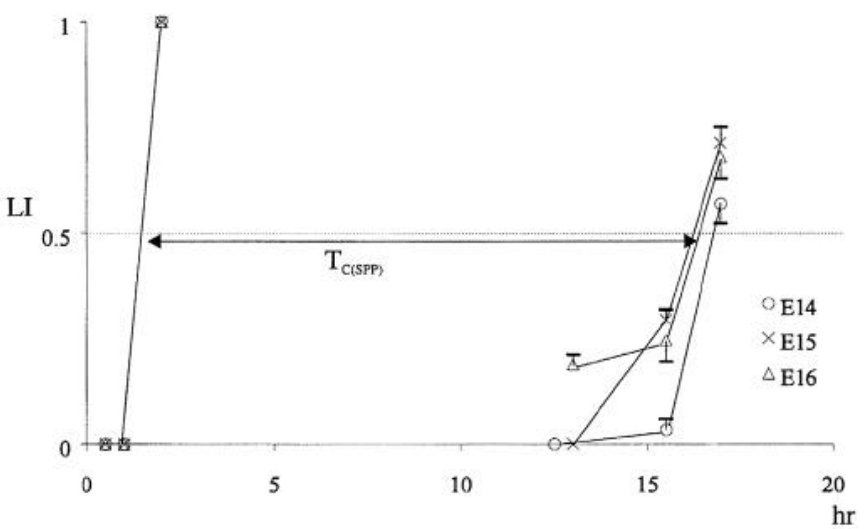

Figure 7. The percent labeled mitosis method of determining the cell cycle length of the SPP. As the nuclei labeled in S phase move through $\mathrm{G} 2$ and $\mathrm{M}$ phases, the proportion of labeled mitotic figures is observed to rise sharply to $100 \%$. It then declines as cells which entered S phase at some time beyond the labeling effectiveness of the single injection entered $\mathrm{M}$ phase. Eventually, the proportion of labeled mitotic figures is seen to rise again as the postmitotic daughter cells, labeled by the injection, complete another G2 phase and enter M phase. We have plotted only the ascending phase of labeling. The cell cycle length of the SPP $\left(T_{C\left(S P P_{1}\right)}\right)$ is estimated as the length of the interval between the $50 \%$ mitotic labeling percentage in the two successive cycles (arrows). Each time point plotted here represents the mean value of 12 animals from two separate litters. Vertical bars $=$ SEM.

atively brief exposure to ${ }^{3} \mathrm{H}$-TdR, we expect $N_{1}$ hr to be underestimated. The magnitude of the underestimate will correspond to the fraction of the hour after injection required for initial ${ }^{3} \mathrm{H}-$ TdR incorporation. This error would not affect the estimates of growth and cell output rate of the SPP because only the relative size change but not the actual size of the population is used for the estimation. Therefore, we will come back to this issue later when we estimate the GF in the zone of the SPP. The estimates of $N_{\mathrm{SPP}}, N_{\mathrm{PVE}}$, and $N$ for the total proliferative population (i.e., $N_{\mathrm{SPP}}+\mathrm{N}_{\mathrm{PVE}}$ ), estimated by Equation 2 above, are entered in Table 1, column 4, and Figure 8.

Relative sizes of the SPP and PVE

From $N_{\mathrm{SPP}}$ and $N_{\mathrm{PVE}}$ the proportion of the SPP and PVE as a function of the total proliferative population was calculated and

\section{Table 1. Cell cycle parameters and sizes of the SPP and PVE}

\begin{tabular}{|c|c|c|c|c|c|c|}
\hline $\begin{array}{l}\text { (1) } \\
\text { Age }\end{array}$ & & $\begin{array}{l}\text { (2) } \\
\text { Number of } 1 \\
\text { hr-cohort } \\
\text { cells per unit } \\
\text { of cerebral } \\
\text { wall }\end{array}$ & $\begin{array}{l}\text { (3) } \\
\text { Cell cycle } \\
\text { length (hr) }\end{array}$ & $\begin{array}{l}(4) \\
\text { Number of } \\
\text { proliferative } \\
\text { cells } \\
(2) \cdot(3)\end{array}$ & $\begin{array}{l}(5) \\
\text { Relative } \\
\text { size (\%) }\end{array}$ & $\begin{array}{l}\text { Number of } \\
\text { proliferative } \\
\text { cells corrected } \\
\text { by the factor } \\
\text { of } 1 / 0.75\end{array}$ \\
\hline \multirow{2}{*}{ E14 } & PVE & 6.98 & 15.1 & 105 & 89 & 140 \\
\hline & SPP & 0.85 & 15 & 12.8 & 11 & 17.1 \\
\hline & SPP & 1.10 & 15 & 16.5 & 14 & 22.0 \\
\hline & Total & 7.10 & - & 122 & 100 & 163 \\
\hline \multirow[t]{3}{*}{ E16 } & PVE & 3.66 & 18.4 & 67.3 & 65 & 89.7 \\
\hline & SPP & 2.39 & 15 & 35.9 & 35 & 47.9 \\
\hline & Total & 6.05 & - & 103 & 100 & 137 \\
\hline
\end{tabular}

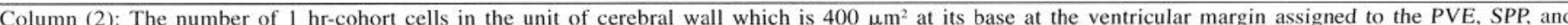

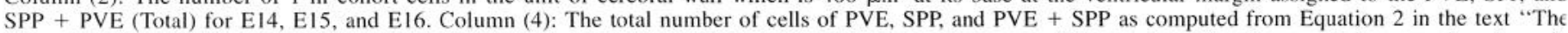

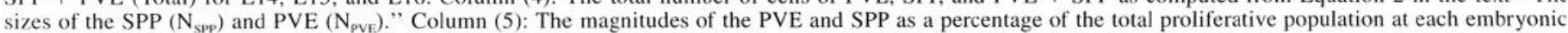
age. Column (6): The values of Column (4) are corrected by the calibration factor, described in the text "GF in the SVZ and IZ." 


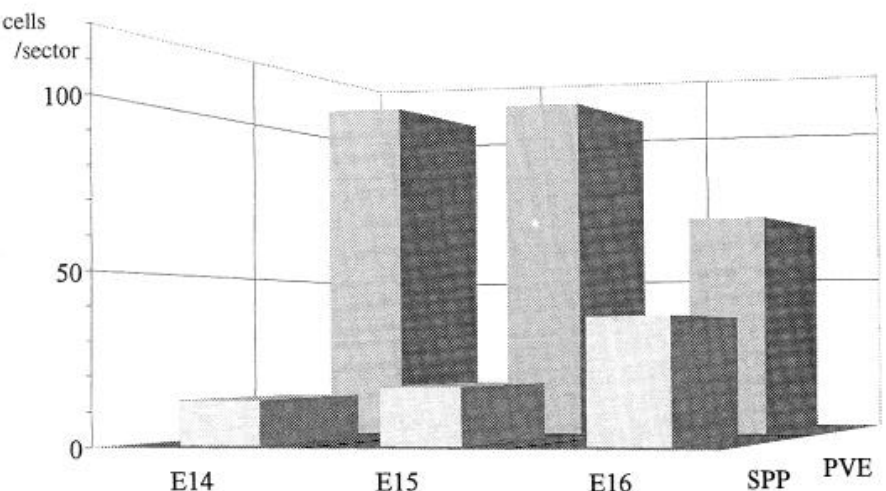

Figure 8. The sizes of the SPP and PVE. The numbers of cells of the PVE and SPP in the standard sector were estimated for E14-E16 from Equation 2 in text section entitled "The sizes of the SPP $\left(N_{\mathrm{SPP}}\right)$ and $\operatorname{PVE}\left(N_{\mathrm{PVE}}\right)$."

entered in Table 1, column 5 and Figure 9. When the SPP initially becomes recognizable as abventricular mitoses at the outer margin of the VZ at E13, it comprises only a small percentage of the total proliferative population. Even $24 \mathrm{hr}$ later on E14, the SPP comprises only about $11 \%$ of the total proliferative population of the cerebral wall. The numbers of cells of the two populations per sector and, therefore, their relative proportions, change relatively little between E14-E15 by which time the number of PVE cells per sector has approached its maximum value (Fig. 8). There follows in the interval E15-E16 a dramatic reciprocal change in the relative abundance of cells of the SPP and PVE. The number per sector of the former increases more than twice while that of the latter becomes reduced by nearly $40 \%$. Thus, on E16 the SPP has become $35 \%$ of the total proliferative population of the cerebral wall (Table 1, column 5, Fig. 9), corresponding to about a $300 \%$ relative increase in a 48 $\mathrm{hr}$ period. Over the subsequent $48 \mathrm{hr}$, that is, during the E16E18 interval, this trend continues (Fig. 9). Thus, the PVE ceases to exist on E17 (Takahashi et al., 1995) while the proliferative activity of the SPP continues postnatally and eventually becomes confined to the subependymal layer.

\section{$G F$ in the SVZ and IZ}

While the SPP is increasing as a proportion of the proliferative population over the interval E14-E16 (Table 1, column 5, Fig. 9 ), it is not clear whether the SPP is increasing as a proportion of the total cell population of the SVZ-IZ. This is because the zone of the SPP contains nonproliferative populations (i.e., glial cells in G0 and postmitotic migrating neurons arising from the PVE, Fig. 1). Thus, simple S-phase labeling does not provide an estimate for the sizes of the proliferative and nonproliferative populations in the zone where the SPP spreads. We have estimated here the actual number of SPP cells in each of the bins in the SVZ and IZ. This was done from (1) the number of $1 \mathrm{hr}$ cohort of cells belonging to the SPP (i.e., $N_{1 \text { hr(SPP) }}$ ) in each of the bins (Fig. 6), (2) $T_{C \text { SPP) }}$ (Table 1, column 3), and (3) a correction factor for the sensitivity of the $1 \mathrm{hr}$ cohort method which is described in the following section.

As mentioned in the previous section the number of the SPP cells based on the $1 \mathrm{hr}$ cohort method may be underestimated. In order to increase the accuracy of the estimate of number of the SPP cells in each bin, we "calibrate" the sensitivity of the $1 \mathrm{hr}$ cohort method against that of S-phase labeling with BUdR. Under the present experimental conditions, the sensitivity of the

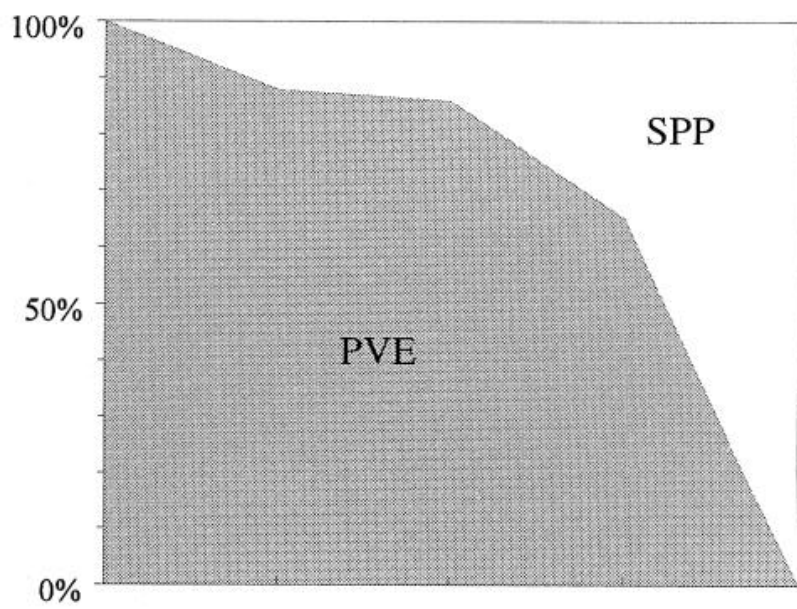

before E13 E14 E15 E16 after E18

Figure 9. Relative sizes of the SPP and PVE. The PVE represents a declining percentage while the SPP represents an increasing percentage of the total proliferative population of the cerebral wall with advance from E13 through E18.

latter method is probably close to $100 \%$ (Takahashi et al., 1992, 1993). Calibration may be done by comparing the sizes of the total proliferative population $\left(N_{T}\right)$ estimated by the two independent methods on E14 when $T_{C}$ values happen to be virtually the same for the PVE and SPP. We assume for this purpose that $T_{S}$ is also the same on E14 for both proliferative populations. For the calculation based upon S-phase labeling with $0.5 \mathrm{hr}$ survival, Equation 1 becomes

$$
N_{T}=N_{S+0.5} * T_{C} /\left(T_{S}=0.5\right) .
$$

$N_{\mathrm{S}+0.5}$ is the number of BUdR labeled cells counted after $0.5 \mathrm{hr}$ BUdR exposure. This is because the effective labeling time of the injected BUdR with the methods we have used here is greater than $0.5 \mathrm{hr}$ (Takahashi et al., 1992). We ignore a delay of approximately $10 \mathrm{~min}$ before $100 \% \mathrm{~S}$-phase labeling is established (Takahashi et al., 1992). The value for $N_{T}$ obtained by the S-phase labeling with BUdR (from Equation 3 is 157 proliferative cells/sector $\left(N_{S+0.5}=44.6, T_{S}=3.8 \mathrm{hr}, T_{C}=15.1 \mathrm{hr}\right.$; Takahashi et al., 1993) whereas the value for $N_{T}$ obtained by the $1 \mathrm{hr}$ cohort method (from Equation 2, $N_{T}=N_{\mathrm{PVE}}+N_{\mathrm{SPP}}$ ) is only 118 proliferative cells/sector (Table 1 , column 4 ). Therefore, the calibration factor would be $118 / 157=0.75$. It thus appears that with the ${ }^{3} \mathrm{H}$-TdR-defined $1 \mathrm{hr}$ cohort we fail systematically to detect the first quarter or so of cells to leave $S$ phase after the tracer injection is given. The GF in the zone where the SPP cells are distributed can be calculated as $\mathrm{GF}=$ number of $1 \mathrm{hr}$ cohort SPP cells in each bin*(1/0.75)/total number of cells in the bin.

The GF profile in "the SPP zone" for E15 and E16 is plotted in Figure 10. The average GF for the entire SPP zone increases from 0.15 on E15 to 0.25 on E16. An estimate of the GF of the SPP at E14 is not attempted here because of its small size at this earlier date. We have also corrected all values of $N$ estimated by the $1 \mathrm{hr}$ cohort method by the factor of $1 / 0.75$ (Table 1 , column 6).

\section{Discussion}

\section{Absolute growth in the size of the SPP}

The measures that have detected the increase in numbers of cells of the SPP (Table 1, column 4, Fig. 8) and the increase in the 


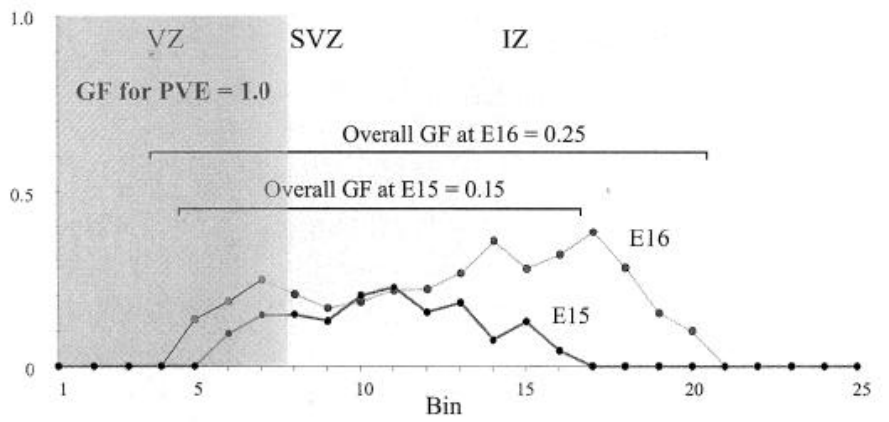

Figure 10. Schematic representation of the growth fractions (GFs, ordinate) with respect to depth in the cerebral wall (bin) at E15 and E16. The number of proliferative cells as a fraction of the total number of cells (= GF) of the PVE is constant at 1.0 , represented as a shaded block within the bins corresponding to the ventricular zone (VZ). GF is plotted for each bin for the cerebral wall where the SPP is distributed. The SPP on E16 has extended more superficially with continued growth of the cerebral wall. The overall GF of the subventricular (SVZ) and intermediate (IZ) zones, that is of the SPP, is higher (0.25) at E16 than at E15 (0.15) but for both days these values are much lower than the GF of the PVE $(=1.0)$.

SPP as a proportion of the total proliferative population of the cerebral wall (Table 1, column 5, Fig. 9) have been undertaken in a standard coronal sector which is $400 \mu \mathrm{m}^{2}$ at its base at the ventricular margin (100 $\mu \mathrm{m}$ medial to lateral in coronal plane $\times 4 \mu \mathrm{m}$ corresponding to section thickness). With increase in the radial dimension of the cerebral wall from $100 \mu \mathrm{m}$ at E14 to almost $400 \mu \mathrm{m}$ at E16 (Fig. 2), the volume of the sector increases from $4 * 10^{4} \mu \mathrm{m}^{3}(4 \mu \mathrm{m} * 100 \mu \mathrm{m} * 100 \mu \mathrm{m})$ to $16^{*} 10^{4}$ $\mu \mathrm{m}^{3}(4 \mu \mathrm{m} * 100 \mu \mathrm{m} * 400 \mu \mathrm{m})$.

Given that $\mathrm{T}_{\mathrm{C}}$ for the SPP holds steady at about $15 \mathrm{hr}$ during the $48 \mathrm{hr}$ interval E14-E16, this would correspond to $3.2 \mathrm{SPP}$ cell division cycles. Had the P fraction of the SPP (the fraction of daughter cells returning to $\mathrm{S}$ phase after mitosis, Takahashi et al., 1994) remained 1.0 throughout this series of cycles and had all SPP progeny remained confined to the sector of cerebral wall having a base of $400 \mu \mathrm{m}^{2}$, the size of the SPP would have doubled with each cycle. This would have had the result that the size of the SPP population would have increased $2^{3.2}=9.2$ fold. An increase of only 2.8 (35.9/12.8 or 47.9/17.1, Table 1, column 4 or 6 ) fold was actually observed within the standard coronal sector. We attribute this disparity to two considerations. First, cells produced within the sector with base of $400 \mu \mathrm{m}^{2}$ would have been displaced with growth in the tangential dimensions of the cerebral wall. Secondly, the value of $P$ for the SPP may be less than 1.0. We are able to estimate the contribution of tangential expansion to the disparity by first estimating the tangential expansion of the PVE and then that of the overlying cerebral wall relative to the PVE. From the residual disparity, we then may estimate the actual value of $P$ for the SPP during the E14-E16 interval.

Expansion of the cerebral wall. Tangential growth of the PVE between E14 and E15 must occur because the $P$ fraction for the PVE at E14 is greater than 0.5 (Takahashi et al., 1994) requiring that there is a net increase in the number of proliferating cells in the epithelium in this interval. We estimate the tangential expansion of the PVE from the following: (1) The expansion of a proliferating population after $n$ cell cycles is $\left(P^{*} 2\right)^{n}$, where $P$ is the fraction of daughter cells that remains in the cell cycle after each cell cycle and $n$ is the number of cell cycles. The $P$ fraction of the PVE at this age is $0.62-0.66$ (median $=0.64$,
Table 2. Expansion of the cerebral wall

\begin{tabular}{|c|c|c|c|}
\hline $\begin{array}{l}\text { (1) } \\
\text { Age }\end{array}$ & $\begin{array}{l}\text { (2) } \\
\text { E14-E15 }\end{array}$ & $\begin{array}{l}(3) \\
\text { E15-E16 }\end{array}$ & $\begin{array}{l}(4) \\
\text { Total } \\
(\text { E14-E16) }\end{array}$ \\
\hline PVE expansion & 1.35 & 0 & 1.35 \\
\hline \multicolumn{4}{|l|}{ IZ expansion relative } \\
\hline to PVE & 1.38 & 1.11 & 1.53 \\
\hline Absolute IZ expansion & 1.86 & 1.11 & 2.06 \\
\hline
\end{tabular}

PVE, Pseudostratified ventricular epithelium; IZ, intermediate zone.

Takahashi et al., 1994), and there are approximately 1.6 cell division cycles in the PVE in $24 \mathrm{hr}$ in the interval E14-15 (Takahashi et al., 1993). (2) There is an approximately $10 \%$ increase in the height of the PVE between E14 and E15 (Fig. 2). (3) The cell packing density within the PVE remains constant at different embryonic ages (Fig. 3). Therefore, the tangential expansion of the PVE in the $24 \mathrm{hr}$ interval, E14-15, is estimated to be approximately $(0.64 * 2)^{1.6 / 1.1}=1.35$ (Table 2, column 2).

As the cerebral wall grows, the IZ expands tangentially more than the $\mathrm{VZ}$. The tangential expansion of the $\mathrm{IZ}$ relative to the ventricular surface of the dorsomedial murine cerebral wall has been previously estimated by measuring the divergence of ascending radial glial fibers in their ascent across the cerebral wall (Gadisseux et al., 1992). Between E14 and E15 the tangential expansion of the IZ, thus estimated, is approximately 1.38 for the E14-E15 interval and the value is 1.11 for E15-E16 so that the total proportionate expansion for E14-E16 is 1.53 (i.e., 1.38*1.11, Table 2, column 4).

The estimate of the expansion of the PVE based upon its values of $P$, taken together with the estimated expansion of the IZ relative to the PVE, indicate that the absolute tangential expansion of the IZ would be $1.35 * 1.38=1.86$ (Table 2 , column 2) between E14 and E15. Beyond E15, $P$ for the PVE has become less than 0.5 (Caviness et al., 1994; Takahashi et al., unpublished observations) so that tangential growth of the PVE may be assumed to have ceased. The expansion factor of only 1.11-fold for the IZ, based upon radial glial fiber divergence, is accepted here as approximately accurate for the E15-E16 interval. Thus, the total estimated expansion of the IZ is then estimated at 2.06 (i.e., $1.86^{*} 1.11$ ).

An estimate of $\mathrm{P}$ fraction for the SPP. As noted above the expansion of a proliferating population after $n$ cell cycles is $\left(P^{*} 2\right)^{n}$. For the SPP, the average value of $P$ for the E14-E15 interval and the E15-E16 interval can now be calculated from the above equation and (1) the number of cell cycles in $24 \mathrm{hr}$ $(=1.6)$ and (2) the expansion of the SPP in $24 \mathrm{hr}$ (2.40 for E14E15 and 2.42 for E15-E16, Table 3, column 3). The $P$ fraction for the SPP is $0.86,0.87$, and 0.87 for E14-15, E15-16, and E14-16, respectively (Table 3 , column 5). $Q(=1-P)$ is 0.14 , 0.13 , and 0.13 for each of these intervals. It follows, therefore, that $87 \%$ of postmitotic cells of the SPP reenter S phase after each cell division in the E14-E16 interval and that only $13 \%$ of the proliferative population exits the cycle. To the extent that cell death, although not recognized here, is occurring in the SPP (Acklin and van der Kooy, 1993), it would further reduce the apparent value of $Q$. In that $Q$ is estimated here to be approximately 0.13 over the E14-16 interval, the rate of cell death must be no greater than this fraction. 
Table 3. Estimate of $P$ fraction for the SPP

\begin{tabular}{lllll} 
& & $\begin{array}{l}\text { (3) } \\
\text { Corrected with }\end{array}$ & & \\
estimated & $\begin{array}{l}\text { (2) } \\
\text { tangential } \\
\text { tissue } \\
\text { expansed } \\
\text { of the SPP }\end{array}$ & $\begin{array}{l}\text { Number of } \\
\text { cell cycles }\end{array}$ & $\begin{array}{l}\text { Estimated } \\
\text { P fraction } \\
\text { of the SPP }\end{array}$ \\
\hline Age & $1.29(16.5 / 12.8)$ & $2.40(1.29 \cdot 1.86)$ & $1.6(24 / 15 \mathrm{hr})$ & 0.86 \\
E14-E15 & $2.18(35.9 / 16.5)$ & $2.42(2.18 \cdot 1.11)$ & 1.6 & 0.87 \\
E15-E16 & 2.81 & 5.81 & 3.2 & 0.87 \\
E14-E16 & & & \\
\hline
\end{tabular}

\section{$S P P$ in relation to $P V E$ and general histogenetic significance}

The $P$ fraction of the SPP remains high through E16 so that the proliferative potential of this population is being continuously augmented in this interval. By contrast the population size of the PVE increases until E15 then declines rapidly. It is only in the terminal $48 \mathrm{hr}$ of gestation in the mouse and the early postnatal period, that the cell output of the SPP appears to accelerate (Misson et al., 1991; Takahashi et al., 1991). Subsequently there will be a corresponding reduction in the size of its proliferative pool of glial cells of the cerebral wall (Schmechel and Rakic, 1979 a; Gressens et al., 1992a,b).

The proliferative behavior of the SPP differs fundamentally from that of the PVE although it arises from that population and coexists with it throughout a sustained period of the cytogenetic epoch. Differences in the properties and proliferative behaviors of the SPP and PVE must reflect the fundamentally different histogenetic roles of the two populations. The PVE is the source of most if not all neocortical neurons (Sidman and Rakic, 1973) although it also includes proliferative radial glial cells which are members of the astroglial lineage (I evitt and Rakic, 1980; Levitt et al., 1981; Misson et al., 1988, 1991).

The compact architecture of the PVE with its closely regulated schedule of cell production reflects the precision and specificity of the cytogenetic agenda of the epithelium. There is an orderly flow of cells through the cycle with mitosis occurring at the ventricular margin and postmitotic cells ascending the same path as Gl cells toward the outer margin of the epithelium where their paths then diverge (Sauer, 1935; Sauer and Walker, 1959; Boulder Committee, 1970; Waechter and Jaensch, 1972; Sidman and Rakic, 1973; Takahashi et al., 1993, 1994). All cells in this epithelium are pursuing their roles in the overall histogenetic agenda in "real time." None of those which are neuronal progenitors appear to "idle" in G0 state, perhaps facultatively in readiness to respond to histogenetic signals that might or might not eventually come, although some radial glial cells arising in the PVE probably do eventually enter the G0 state (Waechter and Jaensch, 1972; Takahashi et al., 1993). Neurons which arise in the PVE and which will form the neocortex are terminally differentiated cells. Once they have undergone their terminal divisions before exit from the PVE and migrate to the neocortex, they do not return to the proliferative state again (Sidman and Rakic, 1982; Rakic, 1985). The neuronal output of the PVE comprises a richly varied set of projection and interneuronal cell classes and these are formed systematically in an inside-out sequence with respect to their destinations in the neocortex (Sidman and Rakic, 1973; Rakic, 1974; Caviness, 1982; McConnell and Kaznowski, 1991). That is, the neuronal population at any given depth of the cortex will have undergone their terminal divisions in a predictable set of the full succession of cell divi- sions: for example, the large pyramids of layer $\mathrm{V}$ arise in the mouse from the early integer cycles but the small and medium pyramids of neocortical layers II/III from the terminal cycles of the sequence (Caviness, 1982).

The SPP, by contrast, though probably arising from the PVE (Smart, 1972; Altman and Bayer, 1990a), is principally a source of glial cells (Smart and Leblond, 1961; Lewis, 1968; Privat, 1975; Todd and Smart, 1982; LeVine and Goldman, 1988a,b; Levinson and Goldman, 1993). Rarely, neurons have been included with glial cells among clones of cells arising in the cerebral wall (Levinson and Goldman, 1993), and it has been possible in vitro to derive neurons from lineages derived from the SPP (Reynolds and Weiss, 1992; Davis and Temple, 1994). As an example of what may be an unusual histogenetic pattern, large numbers of neurons of the olfactory bulb arise in the SPP of the cerebral wall (Luskin, 1993).

The present observations support the impression that neurons arising from the SPP could be only a small proportion of the number of neurons destined for the neocortex. With respect to the E14-E16 interval of neocortical cytogenesis considered here, both the value of $Q$ for the SPP (i.e., about 0.13) and the size of the SPP population relative to the size of the total proliferative population (i.e., $11-35 \%$ ) are small so that the potential neuronal output must be small relative to that of the PVE during this interval. Neocortical neuronal cytogenesis is completed on E17 (Caviness and Sidman, 1973), at about the same time that proliferative activity in the PVE is concluded (Takahashi et al., 1995). Thus, with respect to the terminal hours of neocortical cytogenesis continuing after E16 and not considered here, at most only a relatively small complement of neurons destined for the neocortex or, possibly, for other neuronal populations of the cerebral hemisphere might arise in the SPP.

The dispersion of cells of the SPP appears to follow more heterogeneous patterns than that of the neurons generated nearby in the PVE. In the course of SPP expansion through the interval E14-E16, the density of these cells remains relatively uniform across the width of the subcortical cerebral wall even as the width of the wall expands. This expansion reflects principally the accommodation of axonal systems arising in the same and opposite hemisphere, both from cortical and subcortical sources. In the rodent optic nerve, axonal activity has been demonstrated to play a role in regulation of glial cell proliferation, survival and distribution (Barres et al., 1992; Barres and Raff, 1993). A similar regulatory relationship between axon and glial cell number may operate to maintain cell density constant in the developing murine cerebral wall. The mechanism of such regulation, for example, in terms of cell cycle length or $Q$ fraction modulation, is unknown.

A second pattern of dispersion of the cellular issue of the SPP 
is delayed beyond the completion of neuronogenesis. In the mouse this phenomenon is initiated explosively over the final days of gestation with dispersion of glial cells through the neocortex, the underlying cerebral wall and, possibly other more remote destinations in the cerebrum. This pattern continues vigorously through the early postnatal days but slows in the course of the first few postnatal weeks. It is likely that at least some of the cells arising in the embryonic SPP and participating in the secondary dispersal retain their proliferative capacities as stem cells (Reynolds and Wise, 1992; Davis and Temple, 1994).

This second pattern of deployment of glial cells must reflect, to some extent, migration of cells from the proliferative pool of SPP cells but these probably contribute only in part. 'I'hus, the SPP is maximally no more than $30 \%$ of cells of the cerebral wall (Fig. 10). Whereas a portion, at least, of the nonproliferative cells must correspond to the massive flux of neurons migrating between PVE and neocortex, others must be the somata of radial glial cells, frozen in the G0 state at least for a time in support of neuronal migration (Schmechel and Rakic, 1979a,b). The radial glial cells whose soma persist in this way in the cerebral wall in the G0 state may represent the apparent $Q$ fraction of either or both the PVE and the SPP.

Both of these early and later patterns of dispersion of the cells of the SPP match the multiple physiologic and structural roles of the astroglial and oligodendroglial cells which stem from this proliferative population of the developing cerebral wall. These roles include regulation of the ionic, transmitter and general metabolic environment of synaptic interaction within the cortex and the formation and maintenance of myelin sheaths as well as other compartmental barriers (Hatten, 1987; Vernadakis, 1988; Tolbert and Oland, 1989; Goffinet, 1990; Barres, 1991; Dermietzel and Krause, 1991; Steindler, 1993). In contrast to the neocortical neurons, population renewal and maintenance functions are sustained by the issue of the SPP. At least certain of these either continue to proliferate slowly as a residual stem cell population or facultatively enter the G0 state over the life of the animal (Smart, 1961; LeVine and Goldman, 1988b; Cameron and Rakic, 1991; Goldman and Vaysse, 1991; Skofr and Knapp, 1991; Levinson and Goldman, 1993).

In conclusion, we have shown that the production of cells by the SPP of the cerebral neocortex is minimal during the period of neuronogenesis. This is consistent with the generally held view that the main functional role of the SPP in the developing neocortex is to produce glial cells. It should be noted that this specialization of a proliferative population does not occur in all regions of the CNS; notably even in the developing archicortex (i.e., subiculum, hippocampus, and dentate gyrus) which apparently lacks an SPP (Nowakowski and Rakic, 1981). In other words, the distinction of cortical areas on a developmental basis is an early occurring phenomenon, and the functional role of the SPP is probably an important one in generating the non-neuronal cells of the areas that have an SPP.

\section{References}

Acklin SE, van der Kooy D (1993) Clonal heterogeneity in the germinal zone of developing rat telencephalon. Development 118:175192.

Altman J, Bayer SA (1990a) Vertical compartmentation and cellular transformations in the germinal matrices of the embryonic rat cerebral cortex. Exp Neurol 107:23-35.

Altman J, Bayer SA (1990b) Horizontal compartmentation in the germinal matrices and intermediate zone of the embryonic rat cerebral cortex. Exp Neurol 107:36-47.
Angevine JB, Sidman RL (1961) Autoradiographic study of cell migration during histogenesis of the cerebral cortex in the mouse. Nature 192:766-768.

Barres B (1991) New roles for glia. J Neurosci 11:3685-3694.

Barres BA, Raff MC (1993) Proliferation of oligodendrocyte precursor cells depends on electrical activity in axons. Nature 361:258-260.

Barres BA, Hart IK, Coles SR, Burne JF, Voyvodic JR, Richardson WD, Raff MC (1992) Cell death and control of cell survival in the oligodendrocyte lineage. Cell 70:31-46.

Bayer SA, Altman J (1991) Neocortical development. New York: Raven.

Berry M, Rogers AW (1965) The migration of neuroblasts in the developing cerebral cortex. J Anat 99:691-701.

Boulder Committee (1970) Embryonic vertebrate nervous system: revised terminology. Anat Rec 166:257-262.

Cai L, Hayes NL, Nowakowski RS (1993) Comparison of the cumulative S-phase labeling method and the percent labeled mitoses method in the developing cerebral cortex. Soc Neurosci Abstr 19:30.

Cameron RS, Rakic P (1991) Glial cell lineage in the cerebral cortex: a review and synthesis. Glia 4:124-137.

Caviness VS Jr (1982) Neocortical histogenesis in normal and reeler mice: a developmental study based upon $\left[{ }^{3} \mathrm{H}\right]$ thymidine autoradiography. Dev Brain Res 4:293-302.

Caviness VS Jr, Sidman RL (1973) Time of origin of corresponding cell classes in the cerebral cortex of normal and reeler mutant mice: an autoradiographic analysis. J Comp Neurol 148:141-152.

Caviness VS Jr, Takahashi T, Nowakowski RS, Tsai L (1994) Regulated and nonregulated parameters of neocortical cytogenesis. In: Structural and functional organization of the neocortex (Albowitz $\mathrm{B}$, Albus K, Kuhnt U, Nothdurft H-C, Wahle P, eds), pp 8-22. Berlin: Springer.

Davis AA, Temple S (1994) A self-renewing multipotential stem cell in embryonic rat cerebral cortex. Nature 372:263-266.

Dermietzel R, Krause D (1991) Molecular anatomy of the blood-brain barrier as defined by immunocytochemistry. Int Rev Cytol 127:57109.

Fernandez V, Bravo H (1974) Autoradiographic study of the cerebral cortex in the rabbit. Brain Behav Evol 9:317-332.

Fujita S (1960) Mitotic pattern and histogenesis of the central nervous system. Nature 185:702-703.

Fujita S (1963) The matrix cell and cytogenesis in the developing central nervous system. J Comp Neurol 120:37-42.

Gadisseux JF, Evrard P, Misson JP, Caviness VS, Jr (1992) Dynamic changes in the density of radial glial fibers of the developing murine cerebral wall: a quantitative immunohistological analysis. J Comp Neurol 322:246-254.

Goffinet AM (1990) Determinants of nerve cell patterns during development: a review. Eur J Morphol 28:149-168.

Goldman JE, Vaysse PJ (1991) Tracing glial cell lineages in the mammalian forebrain. Glia 4:149-156.

Gressens P, Lammens M, Picard JJ, Evrard P (1992a) Ethanol-induced disturbances of gliogenesis and neuronogenesis in the developing murine brain: an in vitro and in vivo immunohistochemical and ultrastructural study. Alcohol Alcohol 27:219-226.

Gressens P, Richelme C, Kadhim HJ, Gadisseux JF, Evrard P (1992b) The germinative zone produces the most cortical astrocytes after neuronal migration in the developing mammalian brain. Biol Neonate 61:4-24.

Halliday AL, Cepko CL (1992) Generation and migration of cells in the developing striatum. Neuron $9: 15-26$.

Hatten ME (1987) Neuronal inhibition of astroglial cell proliferation is membrane mediated. J Cell Biol 104:1353-1360.

Hinds JW (1968) Autoradiographic study of histogenesis in the mouse olfactory bulb. II. Cell proliferation and migration. J Comp Neurol 134:305-321

Hinds JW, Ruffett TL (1971) Cell proliferation in the neural tube: an electron microscopic and Golgi analysis in the mouse cerebral vesicle. Z Zcllforsch 115:226-264.

His W (1889) Die Neuroblasten und deren Entstehung im embryonalen Mark. Abh Math Phys Cl, Kgl Saechs Ges Wiss 15:313-372.

His W (1904) Die Entwicklung des Menschlichen Gehirns während der ersten Monate. Leipzig: von S. Hirzel.

Hoshino K, Matsuzawa T, Murakami U (1973) Characteristics of the cell cycle of matrix cells in the mouse embryo during histogenesis of telencephalon. Exp Cell Res 77:89-94. 
Jackson CA, Hickey TL (1985) Use of ferrets in studies of the visual system. Lab Anim Sci 35:211-215.

LeVine SM, Goldman JE (1988a) Embryonic divergence of oligodendrocyte and astrocyte lineages in developing rat cerebrum. J Neurosci 8:3992-4006.

LeVine SM, Goldman JE (1988b) Spatial and temporal patterns of oligodendrocyte differentiation in rat cerebrum and cerebellum. J Comp Neurol 277:441-455.

Levinson SW, Goldman JE (1993) Both oligodendrocytes and astrocytes develop from progenitors in the subventricular zone of the postnatal rat forebrain. Neuron 10:201-212.

Levitt P, Cooper ML, Rakic P (1981) Coexistence of neuronal and glial precursor cells in the cerebral ventricular zone of the fetal monkey: an ultrastructural immunoperoxidase analysis. J Neurosci 1:27-39.

Levitt P, Rakic P (1980) Imunoperoxidase localization of glial fibrillary acidic protein in radial glial cells and astrocytes of the developing rhesus monkey brain. J Comp Neurol 193:815-840.

Lewis PD (1968) Mitotic activity in the primate subependymal layer and the genesis of gliomas. Nature 217:974-975.

Lois C, Alvarez-Buylla A (1994) Long-distance neuronal migration in the adult mammalian brain. Science 264:1145-1148.

Luskin MB (1993) Restricted proliferation and migration of postnatally generated neurons derived from the forebrain subventricular zone. Neuron 11:173-189.

Luskin MB, Shatz CJ (1985) Neurogenesis of the cat's primary visual cortex. J Comp Neurol 242:611-631.

Luskin MB, Breding E, Miller KE, Maulsby M (1992) Cells destined for the olfactory bulb originate in the telencephalic subventricular zone and reach their target by migrating along a restricted longitudinal patluay. Soc Neurosci Abstr 18:924.

Mares V, Bruckner G (1978) Postnatal formation of non-neuronal cells in the rat occipital cerebrum: an autoradiographic study of the time and space pattern of cell division. J Comp Neurol 177:519-528.

McConnell SK (1988) Fates of visual cortical neurons in the ferret after isochronic and heterochronic transplantation. $J$ Neurosci 8:945974.

McConnell SK, Kaznowski CE (1991) Cell cycle dependence of laminar determination in developing neocortex. Science 254:282-285.

Misson J-P, Edwards MA, Yamamoto M, Caviness VC Jr (1988) Mitotic cycling of radial glial cells of the fetal murine cerebral wall: a combined autographic and inmunohistochemical study. Dev Brain Res 38:183-190.

Misson J-P, Takahashi T, Caviness VS Jr (1991) Ontogeny of radial and other astroglial cells in murine cerebral cortex. Glia 4:138-148.

Morshead CM, van der Kooy D (1992) Postmitotic death is the fate of constituitively proliferating cells in the subependymal layer of the adult mouse brain. J. Neurosci 12:249-256.

Nowakowski RS, Rakic P (1981) The site of origin and route and rate of migration of neurons to the hippocampal region of the rhesus monkey. J Comp Neurol 196:129-154.

Patterson JA, Privat A, Ling EA, Leblond CP (1973) Investigation of glial cells in semithin sections. III. Transformation of subependymal cells in glial cells, as shown by radioautography after ${ }^{3} \mathrm{H}$-thymidine injection into the lateral ventricle of the brain of young rats. J Comp Neurol 149:83-102.

Privat A (1975) Postnatal gliogenesis in the mammalian brain. Int Rev Cytol 40:281-323.

Rakic P (1974) Neurons in rhesus monkey visual cortex: systematic relation between time of origin and eventual disposition. Science 183: $42.5-427$

Rakic P (1985) Limits of neurogenesis in primates. Science 227:10541056.

Rcynolds BA, Weiss S (1992) Generation of neurons and astrocytes from isolated cells of the adult mammalian central nervous system. Science 255:1707-1710.

Sauer FC (1935) Mitosis in the neural tube. J Comp Neurol 62:377405.

Sauer FC (1936) The interkinetic migration of embryonic epithelial nuclei. J Morphol 60:1-11.

Sauer FC (1937) Some factors in the morphogenesis of vertebrate embryonic epithelia. J Morphol 61:563-579.
Sauer ME, Walker BE (1959) Radioautographic study of interkinetic nuclear migration in the neural tube. Proc Soc Ext Biol 101:557-560.

Schaper A (1897) Die frühesten Differenzierungsvorgänge im Centralnervensystem. Arch Entwicklungsmech Organ 5:81-132.

Schmechel DE, Rakic R (1979a) Arrested proliferation of radial glial cells during midgestation in rhesus monkey. Nature 277:303-305.

Schmechel DE, Rakic P (1979b) A Golgi study of radial glial cells in developing monkey telencephalon: norphogenesis and transformation into astrocytes. Anat Embryol 156:115-152.

Schultz B, Nowak B, Maurer W (1974) Cycle times of the neural epithelial cells of various types of neuron in the rat. An autoradiographic study. J Comp Neurol 158:207-218.

Shimada M, Langman J (1970) Cell proliferation, migration and differentiation in the cerebral cortex of the golden hamster. J Comp Neurol 139:227-244.

Sidman RL (1970) Autoradiographic methods and principles for study of the nervous system with thymidine-H3. In: Contemporary research methods in neuroanatomy (Nauta WJH, Ebbesson SOE, eds), pp 252274. New York: Springer.

Sidman RL, Rakic P (1973) Neuronal migration, with special reference to developing human brain: a review. Brain Res 62:1-35.

Sidman RL, Rakic P (1982) Development of the human entral nervous system. In: Histology and histopathology of the nervous system (Haymaker W, Adams RD, eds), pp 3-145. Springfield: Thomas.

Sidman RL, Miale IL, Feder N (1959) Cell proliferation and migration in the primitive ependymal zone: an autoradiographic study of histogenesis in the nervous system. Exp Neurol 1:322-333.

Skott RP, Knapp PE (1991) Division of astroblasts and oligodendroblasts in postnatal rodent brain: evidence for separate astrocyte and oligodendrocyte lineages. Glia 4:165-174.

Smart I (1961) The subependymal layer of the mouse brain and its cell production as shown by autoradiography after thymidine- $\mathrm{H} 3$ injection. J Comp Neurol 116:325-347.

Smart I, Leblond CP (1961) Evidence for division and transformation of neuroglia cells in the mouse brain, as derived from radioautography after injection of thymidine-H3. J Comp Neurol 116:349-367.

Smart IHM (1972) Proliferative characteristics of the ependymal layer during the early development of the mouse diencephalon, as revealed by recording the number, location, and plane of cleavage of mitotic cells. J Anat 113:109-129.

Steindler DA (1993) Glial boundaries in the developing nervous system. In: Annual review of neuroscience, pp 445-470. Palo Alto: Annual Reviews.

Stensaas LJ, Stensaas S (1968) An electron microscope study of cells in the matrix and intermediate laminae of the cerebral hemisphere of the $45 \mathrm{~mm}$ rabbit embryo. Z Zellforsch 91:341-365.

Takahashi T, Misson J, Caviness VS Jr (1991) Glial process elongation and branching in the developing murine neocortex: a qualitative and quantitative immunohistochemical analysis. J Comp Neurol 302:1528 .

Takahashi T, Nowakowski RS, Caviness VS Jr (1992) BUdR as an $S$-phase marker for quantitative studies of cytokinetic behaviour in the murine cerebral ventricular zone. J Neurocytol 21:185-197.

Takahashi T, Nowakowski RS, Caviness VS Jr (1993) Cell cycle parameters and patterns of nuclear movement in the neocortical proliferative zone of the fetal mouse. J Neurosci 13:820-833.

Takahashi T, Nowakowski RS, Caviness VS Jr (1994) Mode of cell proliferation in the developing mouse neocortex. Proc Natl Acad Sci USA 91:375-379.

Takahashi T, Nowakowski RS, Caviness VS Jr (1995) The cell cycle of the pseudostratified ventricular epithelium of the embryonic murine cerebral wall. J Neurosci 15:6046-6057.

Todd PH, Smart IHM (1982) Growth patterns in the lateral wall of the mouse telencephalon. III. Studies of the chronologically ordered column hypothesis of isocortical histogenesis. J Anat (Lond) 134:633642.

Tolbert LP, Oland LA (1989) A role for glia in the development of organized neuropilar structures. Trends Neurosci 12:70-75.

Vernadakis A (1988) Neuron-glia interrelations. Int Rev Neurobiol 30: $149-224$.

Waechter RV, Jaensch B (1972) Generation times of the matrix cells during embryonic brain development: an autoradiographic study in rats. Brain Res 16:235 250 . 